\title{
Association of HindIII-polymorphism in kappa-casein gene with milk, fat and protein yield in holstein cattle*
}

\author{
Martina Miluchová ${ }^{凶}$, Michal Gábor, Juraj Candrák, Anna Trakovická and Kristína Candráková \\ Department of Genetics and Breeding Biology, Slovak University of Agriculture in Nitra, Nitra, Slovakia
}

\begin{abstract}
The aim of this paper was to evaluate the effect of genetic polymorphism of kappa-casein on milk production in Holstein cattle. Two hundred and ten Holstein cows were used in this study. We established genotype structure of cattle population and calculated allelic frequencies based on PCR-RFLP analyses. The three genotypes: AA (69.52\%), AB (27.62\%), and BB (2.86\%) were detected. Frequency of allele $A$ was $83.33 \%$, and of allele B $16.67 \%$. The Holstein cattle kept in Slovak Republic exhibit a high value of homozygosity (0.7222) and low values of polymorphism information content (0.2392), effective number of alleles (1.3847) and level of possible variability realization $(27.91 \%)$. The effect of polymorphism of CSN3 gene on average breeding values for milk production traits, such as yield of milk, fat and protein expressed in kilograms, as well as percentage content of fat and protein in milk, has been assessed. In our assessment of the observed traits' variability's dependence on CSN3 gene polymorphism, we detected a statistically significant difference between genotypes only in case of the average breeding value for the percentage of protein in milk.
\end{abstract}

Key words: Holstein cattle, milk production, CSN3, kappa-casein, genetic structure

Received: 02 September, 2017; revised: 09 June, 2018; accepted: 15 August, 2018; available on-line: 15 September, 2018

e-mail: martina.miluchova@centrum.sk, martina.miluchova@ uniag.sk

* Preliminary report presented: Association of kappa-casein gene polymorphism with milk yield, fat and protein in holsteincattle. 6th Central European Congress of Life Sciences. EUROBIOTECH, 11-14 September, 2017, Kraków, Poland

Abbreviations: CSN3, kappa-casein; d.f., degrees of freedom; Heobs, experimental heterozygosity; Heexp, theoretical heterozygosity; PIC, polymorphism information content; $E$, expected homozygosity; ENA, effective number of alleles; V\%, level of possible variability realization

\section{INTRODUCTION}

Milk and dairy products such as cheese, yoghurt, butter and many others, are a rich source of proteins and minerals and hence constitute an important part of human nutrition. Improvement of milk yield and its composition is a primary goal of animal selection in dairy industry (Caroli et al. 2009; Gouda et al., 2013). The nutritional and technological quality of milk is influenced by breed, dietary factors (Dewhurst et al., 2006; Chilliard et al., 2007; Gálik et al., 2011; Šimko et al., 2014), environment (Vidra et al., 2000; Śt'astná \& Št'astný, 2016), health (Št'astná \& Št'astný, 2015a, 2015b) and genetic background of the cows (Vidra et al., 2001; Stoop et al., 2009; Marchitelli et al., 2013). One way to improve milk, milk fat, and milk protein production is through animal selection based on molecular markers (Riaz et al., 2008). Kumar and coworkers (Kumar et al., 2006) reported that DNA polymorphic markers enable for determination of individual genotypes at many loci and provide information on population parameters such as allelic and genotypic frequencies, and can be used as a tool for improving animal selection. Analysis of the milk protein related polymorphism provides a useful information to both the breeders and the processors of milk. Many research reports have indicated that certain milk protein variants may be associated with milk production, milk composition (Robitaille et al., 2002) and the effectiveness of cheese production (Riaz et al., 2008). Genomic variation in the $x-\mathrm{CN}$ locus has been strongly associated with differences in milk composition, its processing properties and resulting dairy products (Riaz et al., 2008). In cattle, CSN3 presents two most common alleles $\mathrm{A}$ and $\mathrm{B}$. The kappa-casein B allele is related to milk production, and more favourable chemical composition and technological parameters of milk, such as thermal resistance, 10-30\% shorter coagulation time, coagulum firmness greater by $20-100 \%$, as well as $5-8 \%$ increased efficiency of both fresh and mature cheese production, as compared to allele A (Litwińczuk et al., 2004; Sitkowska et al., 2008; Doosti et al., 2011).

This report aimed to evaluate the effect of genetic polymorphism of kappa-casein on the milk production traits of Holstein cows.

\section{MATERIALS AND METHODS}

Animals. A total 210 of Holstein cows were used in this study. Samples of animals' hair came from two farms. Sampling strategy was as follows: in every farm the samples were collected from approximately the same numbers of the top, the average and the worst ranked animals in each herd, based on the Slovak Production Index. Slovak Production Index is the Slovak Selection Index of aggregate genotypes of breeding values for milk, fat and protein yield. Genomic DNA was isolated from the samples of hair roots by using commercial column kit QIAamp ${ }^{\circledR}$ DNA Mini Kit (Qiagen). The concentration and purity of DNA was measured using a spectrophotometer NanoPhotometer ${ }^{\mathrm{TM}}$ (Implen $\mathrm{GmbH}$ ). The DNA samples were stored at $-20^{\circ} \mathrm{C}$.

Genotyping. For genotyping of $\mathrm{A} \rightarrow \mathrm{C}$ CSN3 gene polymorphism in position 5345 of X14908 sequence (Gen.Bank No.), we used the PCR-RFLP method as described by Schlieben et al. (1991).

PCR amplification. The amplification of $443 \mathrm{bp}$ fragment of CSN3 gene was done using the following specific primers: forward primer 5'-GCTGAGCAGGTATCCTAGTTAT-3', reverse primer 5'-CT'TCT'T'T- 
GATGTCTCCT'TAGAG-3'. The PCR reactions were run in a gradient thermocycler C1000 Touch TM (Biorad). Each reaction mixture had a total volume of $25 \mu \mathrm{l}$ and contained $50 \mathrm{ng}$ DNA, $1.5 \mathrm{U}$ Taq polymerase (Thermo Scientific), 1X PCR buffer $(750 \mathrm{mM}$ Tris- $\mathrm{HCl}, \mathrm{pH} 8.8$, $200 \mathrm{mM}\left(\mathrm{NH}_{4}\right)_{2} \mathrm{SO}_{4}, 0.1 \%$ Tween 20), $1.5 \mathrm{mM} \mathrm{MgCl}_{2}$, $200 \mu \mathrm{M}$ dNTP, and $5 \mathrm{pM}$ of each primer. The following amplification parameters were applied: $95^{\circ} \mathrm{C}$ for 5 minutes followed by 30 cycles of $95^{\circ} \mathrm{C}$ for 10 seconds, $55^{\circ} \mathrm{C}$ for 30 seconds and $72^{\circ} \mathrm{C}$ for 30 seconds. The reaction was completed by the final synthesis: $72^{\circ} \mathrm{C}$ for $5 \mathrm{~min}-$ utes.

RFLP analysis. After PCR reaction was finalized, the samples were genotyped using RFLP analysis. The 443 bp PCR products were digested with 5 units of HindIII restriction enzyme (Thermo Scientific). Restriction digestion fragments were loaded on $2 \%$ agarose gel (Invitrogen) containing GelRed ${ }^{\mathrm{TM}}$ (Biotium) in $1 \times \mathrm{SB}$ buffer (Brody \& Kern, 2004) at $180 \mathrm{~V}$ for 15 minutes. Then the gels were analyzed with the UV rays and a documentary system Olympus C-7070 was used to record the results.

Genetic structure. We determined the genotypic structure of the population studied for CSN3 gene and estimated the allelic frequencies using molecular genetics analyses. A statistical significance of the differences between experimental and theoretically expected frequencies of genotypes was calculated with the $\chi^{2}$-test. Effectiveness of allele incidence was evaluated with the following parameters: theoretical heterozygosity $\left(H e_{\exp }\right)$, experimental heterozygosity $\left(\mathrm{H}_{\mathrm{obs}}\right)$, polymorphism information content (PIC), expected homozygosity (E), effective number of alleles (ENA), and level of possible variability realisation $(\mathrm{V} \%)$.

- Theoretical heterozygosity $\left(H e_{\text {exp }}\right)(\mathrm{Nei}, 1973)$

$$
H e_{\exp }=1-\sum\left(p^{2}+q^{2}\right)
$$

- Polymorphism information content (PIC) (Boltstein et al., 1980)

$$
P I C=1-\sum\left(p^{2}+q^{2}\right)-\left(\sum_{i=1}^{n-1} \sum_{j=i+1}^{n} 2 p_{i}^{2} p_{j}^{2}\right)
$$

- Expected homozygosity (E) (Crow \& Kimura, 1970)

$$
E=\sum p^{2}
$$

- Effective number of alleles (ENA) (Crow \& Kimura, 1970)

$$
E N A=\frac{1}{p^{2}+q^{2}}
$$

- Level of possible variability realization ( $V \%$ ) (Crow \& Kimura, 1970)

$$
V=\frac{1-E}{1-\frac{1}{N}} \times 100
$$

Association studies. For the association study we used five breeding values of the cows (milk, fat and protein yield expressed in kilograms, and milk's fat and protein percentage) as the phenotype values. Breeding values were estimated based on the national Test-Day-Animal model. We analyzed the breeding values already corrected for the other factors (age, number of lactations, season). The results of molecular genetic analysis were used to confirm a relationship between polymorphism of CSN3 gene and the production traits.

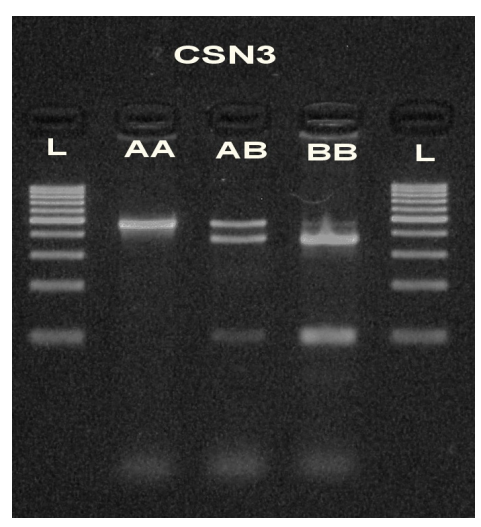

Figure 1. Illustration of CSN3 genotypes on agarose gel.

Genotype AA (443 bp), genotype AB (443 bp, 348 bp, 95 bp), genotype BB (348 bp, 95 bp), L - 100 bp ladder (Thermo Scientific BioScience)

To describe the effect of CSN3 genotypes on the average breeding values for milk, fat and protein yield expressed in kilograms, as well as fat and protein percentage of milk, a statistical analysis was used. The impact of individual genotypes of CSN3 gene on the variability of average breeding values was evaluated using a two-way analysis of variance:

$$
y=\mu+G_{\mathrm{i}}+S_{\mathrm{j}}+e_{\mathrm{ij}}
$$

$y$ - breeding value ( $\mathrm{kg}$ milk, $\mathrm{kg}$ protein, $\mathrm{kg}$ fat, $\%$ protein, $\%$ fat); $\mu$ - mean value; $G_{i}$ - fixed effect of genotype, ${ }_{i}=1,2,3 ; S_{j}$ - fixed effect of herd, ${ }_{i}=1,2 ; e_{i j}-$ residual effect.

To test the influence of CSN3 genotypes on variability of the average breeding values for milk, fat and protein yield, as well as fat and protein percentage of milk, we used SAS package, version 9.3 (SAS Inc., 2011).

\section{RESULTS}

The CSN3 genotypes of Holstein cows were determined using PCR-RFLP, with the following separation of allele-specific fragments in 2\% agarose gel (Fig. 1).

Genotype and allele frequencies of Holstein cattle for CSN3 are shown in Table 1.

Genetic equilibrium of analysed population was evaluated based on the $\chi^{2}$-test. In the population included in the study, the differences in frequencies of genotypes for CSN3 gene were not significant. Effectiveness of alleles CSN3 in tested population is shown in Table 2.

During our assessment of the variability of the observed traits dependence on CSN3 gene polymorphism, we detected a statistically significant difference between genotypes only in case of the average breeding value for the percentage of protein in milk (Fig. 3). For the other breeding values, the impact of individual CSN3 genotypes on their variability was not observed (Fig. 2 and Fig. 3). The average breeding values for milk production traits of Holstein cows in relation to analyzed CSN3 genotypes are shown in Table 3.

We found a statistically significant difference between CSN3 genotypes' effect on the average breeding value for protein content of milk. Statistical analysis confirmed that the AA genotype significantly reduces the average value of the protein content of milk $(0.09 \%$ on average), compared with genotype BB. 
Table 1. Genotype and allele frequencies of Holstein cattle for CSN3

\begin{tabular}{|c|c|c|c|c|c|c|c|}
\hline \multirow[t]{2}{*}{ Locus } & \multicolumn{3}{|c|}{ Genotype frequencies } & \multicolumn{2}{|c|}{ Allelic frequencies } & \multirow[t]{2}{*}{$x^{2}$} & \multirow[t]{2}{*}{$P$} \\
\hline & AA & $A B$ & BB & A & $B$ & & \\
\hline CSN3 & 0.6952 & 0.2762 & 0.0286 & 0.8333 & 0.1667 & 0.007 & 0.9967 \\
\hline
\end{tabular}

Table 2. Effectiveness of CSN3 alleles in Holstein cattle population

\begin{tabular}{lllllllll}
\hline Locus & Alleles & Heobs & Heexp & PIC & E & ENA & V \% \\
\hline CSN3 & A; B & 0.2762 & 0.2778 & 0.2392 & 0.7222 & 1.3847 & 27.91 \\
\hline
\end{tabular}

Table 3. Average breeding values for milk production traits of Holstein cows with different CSN3 genotypes

\begin{tabular}{|c|c|c|c|c|c|c|c|}
\hline Genotype & Number & $\begin{array}{l}\text { Breeding va- } \\
\text { lues }\end{array}$ & Average & Standard error & Minimum & Maximum & $P$-value \\
\hline AA & 146 & $\begin{array}{l}\text { BVM } \\
\text { BVF } \\
\text { BVF\% } \\
\text { BVP } \\
\text { BVP\% }\end{array}$ & $\begin{array}{l}850.1650685 \\
13.7454110 \\
-0.2465068 \\
20.0867123 \\
-0.0974658^{++}\end{array}$ & $\begin{array}{l}560.8474392 \\
15.5539216 \\
0.2208966 \\
13.9646545 \\
0.1390302\end{array}$ & $\begin{array}{l}-606.6000000 \\
-21.2700000 \\
-0.6100000 \\
-14.6500000 \\
-0.3900000\end{array}$ & $\begin{array}{l}1977.40 \\
56.9100000 \\
0.4800000 \\
49.5100000 \\
0.3400000\end{array}$ & $\begin{array}{l}\text { n.s. } \\
\text { n.s. } \\
\text { n.s. } \\
\text { n.s. } \\
0,002\end{array}$ \\
\hline$A B$ & 58 & $\begin{array}{l}\text { BVM } \\
\text { BVF } \\
\text { BVF\% } \\
\text { BVP } \\
\text { BVP\% }\end{array}$ & $\begin{array}{l}713.5603448 \\
12.2413793 \\
-0.2051724 \\
19.7758621 \\
-0.0393103\end{array}$ & $\begin{array}{l}551.7021949 \\
16.2296974 \\
0.1834680 \\
16.8919232 \\
0.1038363\end{array}$ & $\begin{array}{l}-595.1000000 \\
-26.7500000 \\
-0.4900000 \\
-16.7100000 \\
-0.3800000\end{array}$ & $\begin{array}{l}2026.50 \\
57.1300000 \\
0.2900000 \\
63.8900000 \\
0.1500000\end{array}$ & $\begin{array}{l}\text { n.s. } \\
\text { n.s. } \\
\text { n.s. } \\
\text { n.s. } \\
\text { n.s. }\end{array}$ \\
\hline BB & 6 & $\begin{array}{l}\text { BVM } \\
\text { BVF } \\
\text { BVF\% } \\
\text { BVP } \\
\text { BVP\% }\end{array}$ & $\begin{array}{l}718.7500000 \\
11.5950000 \\
-0.2200000 \\
22.1833333 \\
-0.0016667\end{array}$ & $\begin{array}{l}371.9125852 \\
5.3510550 \\
0.1141928 \\
7.7873556 \\
0.0858875\end{array}$ & $\begin{array}{l}327.1000000 \\
5.4600000 \\
-0.3900000 \\
11.3800000 \\
-0.1200000\end{array}$ & $\begin{array}{l}1196.00 \\
18.5800000 \\
-0.1100000 \\
29.7800000 \\
0.1200000\end{array}$ & $\begin{array}{l}\text { n.s. } \\
\text { n.s. } \\
\text { n.s. } \\
\text { n.s. } \\
\text { n.s. }\end{array}$ \\
\hline
\end{tabular}

BVM - breeding values for the yield of milk (kg), BVF - breeding values for the yield of fat (kg), BVF\% - breeding values for the contents of fat (\%), BVP - breeding values for the yield of protein (kg), BVP\% - breeding values for the contents of protein (\%), $P \leq 0.01$ - statistically highly significant $(++), P \leq 0.05$ - statistically significant (+), $P \geq 0.05$ - statistically non-significant (n.s.)

\section{CSN3}

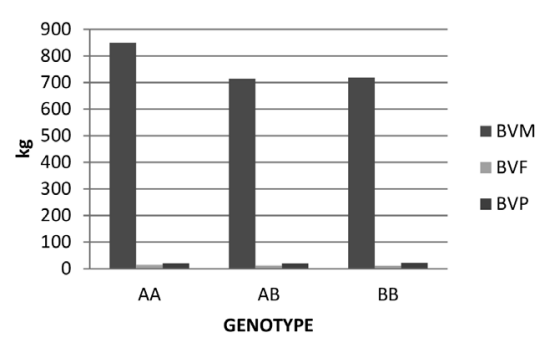

Figure 2. Effect of different CSN3 genotypes on the average breeding values for the yield of milk, fat and protein shown in kilograms

\section{DISCUSSION}

\section{Genetic structure}

Using a molecular-genetic PCR-RFLP method for CSN3 genotyping in Holstein cattle population kept in Slovakia, we detected a predominance of the AA genotype $(69.52 \%)$; a lower frequency of the $\mathrm{AB}$ genotype $(27.62 \%)$ and the least representation of the BB genotype $(2.86 \%)$.

The frequency of allele $\mathrm{A}$ was very high in the population and amounted to $83.33 \%$. The frequency of allele $\mathrm{B}$ was $16.67 \%$. The results of our study are compatible with the results of Botaro and others (Botaro et al., 2009), who found a considerable predominance of the AA genotype in the population of Holstein cattle, with the AA genotype frequency of $66.83 \%$, the AB genotype frequency of $31.84 \%$ and the lowest $\mathrm{BB}$ genotype fre-

\section{CSN3}

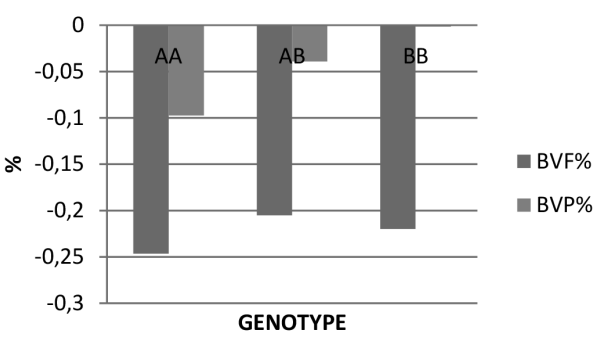

Figure 3. Effect of different CSN3 genotypes on the average breeding values for fat and protein percentage of milk

quency of $1.33 \%$. They also detected predominance of the allele A $(82.75 \%)$ over the allele B $(17.25 \%)$ in the tested population. Similarly, Sitkowska and others (Sitkowska et al., 2008) observed a high proportion of the AA genotype in the population of Holstein cows, with the AA genotype frequency of $71 \%$, the $\mathrm{AB}$ genotype present in $23 \%$ of the cattle and the BB genotype present in only $6 \%$ of the animals. These data suggested the advantage of the allele $\mathrm{A}$, with its frequency of $83 \%$, while frequency of the B allele was 17\%. Gouda and others (Gouda et al., 2013) observed only two genotypes in a population of Holstein cows. The $\mathrm{AB}$ genotype was represented by $76 \%$ of cows, and the AA genotype was represented by $24 \%$ of cows, and the frequencies of the $\mathrm{A}$ and $\mathrm{B}$ alleles were $62 \%$ and $38 \%$, respectively. In accordance with these results, Doosti and others (Doosti et al., 2011) detected only the $\mathrm{AA}$ and $\mathrm{AB}$ genotypes in the Holstein breed, with a prevalence of $\mathrm{AB}$ genotype 
$(82 \%)$ compared to AA genotype (18\%). The frequencies of the A and B alleles in this study were $59 \%$ and $41 \%$, respectively. The frequencies of the $\mathrm{A}$ and $\mathrm{B}$ alleles of CSN3 gene in Holstein cattle population tested by us, and in the population of Holstein cattle tested by other authors, were similar to those reported by Kučerová and others (Kučerová et al., 2006), Bulla and others (Bulla et al., 2007), Brka and others (2010) in Pinzgau cattle. A higher frequency of the allele A in Slovak Pinzgau cattle population was reported Miluchová and others (Miluchová et al., 2009, Miluchová et al., 2014).

\section{Effectiveness of alleles}

The loss of genetic variation arising from a limited population size in the captive populations is an important concern. The heterozygosity has been widely used as a descriptor because it is proportional to the amount of genetic variance at a locus, and enables for theoretical consideration of the effect of limited population size on genetic variation (Gautschi et al., 2003). In the analysed population of Holstein cattle, the polymorphism of bovine CSN3 gene showed a high proportion of AA homozygosity $(69.52 \%)$, as described with the high value of the coefficient of homozygosity (0.7222). Effectiveness of alleles in a population can be described with the effective number of alleles. In a two-allele system, a limit of 2.0 indicates that both alleles are effectively involved in the development of genotypes. In our case, this value was decreased to 1.3847 , showing that the effect of alleles A and B is not balanced. The PIC value (0.2392) was substantially lower than a threshold value (0.5), also indicating a low polymorphic level. The low level of polymorphism caused a decrease in a level of possible variability realization $(27.91 \%)$.

\section{Association studies}

The most common gene variants $\mathrm{A}$ and $\mathrm{B}$ of CSN3 are shown to be associated with the processing properties of milk (Alipanah et al., 2007; Hamza et al., 2010). Azevedo and others (Azevedo et al., 2008) reported, that the B allele is associated with thermal resistance, by shorter coagulation time (10-30\%), higher yield of fresh and ripe cheeses (5-8\%), better curd firmness (20$100 \%$ ) and micelles of various sizes, necessary for the production of cheese. Kučerová and others (Kučerová et al., 2004) suggest, that the B allele of CSN3 gene is associated with forming of harder and thicker curd as well as with a higher cheese production. Azevedo and others (Azevedo et al., 2008) also argue that the yield of the curd from milk of cows with the BB genotype is $10 \%$ higher compared to cows with AA genotype. Kučerová and others (Kučerová et al., 2004) also present that the AA genotype of CSN3 gene is mostly associated with a higher yield of milk, proteins and fat, opposite to the BB genotype, which is in turn bound with a higher percentage of protein and fat. In our assessment of the variability of observed traits' co-occurrence with a polymorphism of CSN3 gene as described with HindIII restriction analysis of CSN3 gene fragment, we detected statistically significant difference between genotypes only in an average breeding value for the percentage of protein in milk. The statistical analysis presented in this study confirmed that the AA genotype significantly reduces the average breeding value for the percentage of protein in milk by $0.09 \%$, compared to BB genotype. The study by Ziemiński and others (Ziemiński et al., 2005) previously confirmed the association between CSN3 polymorphism and milk production for a higher percentage of protein in milk of cows with the BB genotype, but, in contrast to our finding, they observed also a higher percentage of fat in the milk of cows with BB genotype. According to Patel and others (Patel et al., 2007), the B variant of CSN3 gene has a significant effect on milk yield and milk protein yield. Botaro et al. (2009) reported that cows with the $\mathrm{AB}$ genotype produced milk with a high fat percentage, compared to cows with the $\mathrm{AA}$ and $\mathrm{BB}$ genotypes. Sitkowska and others (Sitkowska et al., 2008) found that the AA genotype of CSN3 increased the yield of milk fat and protein.

\section{CONCLUSION}

The results of our study suggest that CSN3 gene polymorphism has a measurable effect on the average breeding value for the percentage of protein in milk of Holstein cows. Statistical analysis confirmed that the AA genotype significantly reduced the average breeding value for the percentage of protein in milk.

\section{Acknowledgement of Financial Support}

This study was supported by the Slovak Research and Development Agency (Contract No. APVV-14-0054 and APVV-0636-11).

\section{REFERENCES}

Alipanah M, Klashnikova L, Rodionov G (2007) K-casein genotypic frequencies in Russian breed Black and Red Pied cattle. Iran J Biotechnol 3: 191-194

Azevedo ALS, Nascimento CS, Steinberg RS, Carvalho MRS, Peixoto MGCD, Teodoro RL, Verneque RS, Guimarães SEF, Machado MA (2008) Genetic polymorphism of the kappa-casein gene in Brazilian cattle. Gen Mol Res 7: 623-630. http://doi.org/10.4238/vol7$3 \mathrm{gmr} 428$

Boltstein D, White RL, Skolnik M, Davis RW (1980) Construction of a genetic linkage map in man using restriction fragment length polymorphism. Amer J Hum Genet 32: 314-331

Botaro, BG, De Lima YVR, Cortinhas CS, Silva LFPE, Rennó FP., Dos Santos MV (2009) Effect of the kappa-casein gene polymorphism, breed and seasonality on physicochemical characteristics, composition and stability of bovine milk. R Bras Zootec 38: 24472454. http://dx.doi.org/10.1590/S1516-35982009001200022

Brka M, Hodžić A, Reinsch N, Zečević E, Dokso A, Djedović R, Rukavina D, Kapur L, Vegara M, Šabanović M, Ravić I (2010) Polymorphism of the kappa-casein gene in two Bosnian autochthonous cattle breeds. Arch Tier: 53: 277-282

Brody RJ, Kern SE (2004) Sodium boric acid: a Tris-free, cooler conductive medium for DNA electrophoresis. Biotechniq 36: 214-216

Bulla J, Chrenek P, Michalcová A, Krupová Z, Szarek J, Bulla R, Ladyková M, Adamczyk K (2007) Influence of $\kappa$-casein and $\beta$-lactoglobulin genes on milk yield, milk composition and technological properties of the different cattle breeds. Biotech 54: 60

Caroli AM, Chessa S, Erhardt GJ (2009) Invited review: Milk protein polymorphisms in cattle: Effect on animal breeding and human nutrition. J Dairy Sci 92: 5335-5352. http://doi.org/10.3168/jds.20092461

Chilliard Y, Glasser F, Ferlay A, Bernard L, Rouel J, Doreau M (2007) Diet, rumen biohydrogenation and nutritional quality of cow and goat milk fat. Eur J Lipid Sci Technol 109: 828-855. http://doi. org/10.1002/ejlt.200700080

Crow JF, Kimura M (1970) An introduction to population genetics theory. Burgess Publishing, Minneapolis

Dewhurst RJ, Shingfield KJ, Lee MRF, Scollan ND (2006) Increasing the concentrations of beneficial polyunsaturated fatty acids in milk produced by dairy cows in high-forage systems. Anim Feed Sci Technol 131: 168-206. https://doi.org/10.1016/j.anifeedsci.2006.04.016

Doosti A, Arshi A, Vatankhah M, Amjadi P (2011) Kappa-casein gene polymorphism in Holstein and Iranian native cattle by polymerase chain reaction restriction fragment length polymorphism (PCRRFLP). African J Biotech 10: 4957-4960. https://doi.org/10.5897/ AJB10.2565

Gálik B, Šimko M, Juráček M, Bíro D, Horniaková E, Rolinec M, Pastierik O, Kolesárová A, Maiorano G, Gambacorta M, Tavaniello S, Bednarczyk M (2011) Biotechnology and animal food quality. SPU, Nitra ISBN 978-80-552-0708-7 
Gautschi B, Müller JP, Schmid B, Shykoff JA (2003) Effective number of breeders and maintenance of genetic diversity in the captive bearded vulture population. Heredity 91: 9-16. https://doi. org $/ 10.1038 /$ sj.hdy. 6800278

Gouda EM, Galal MK, Abdelaziz SA (2013) Genetic variants and allele frequencies of kappa casein in Egyptian cattle and buffalo using PCR-RFLP. J Agric Sci 5: 9752-9760. http://dx.doi.org/10.5539/jas. v5n2p197

Hamza AE, Wang XL, Yang ZP (2010) Kappa casein gene polymorphism in Holstein Chinese cattle. Pak Vet J 30: 203-206

Kučerová J, Matějiček A, Jandurová OM, Sørensen P, Němcová E, Štípková M, Kott T, Bouška J, Frelich J (2006) Milk protein genes CSN1S1, CSN2, CSN3, LGB and their relation to genetic values of milk production parameters in Czech Fleckvieh. Czech J Anim Sci 51: $241-247$

Kučerová J, Němcová E, Štípková M, Vrtková I, Dvořák J, Frelich J, Bouška J, Maršalek M (2004) The influence of markers CSN3 and ETH10 on milk production parameters in Czech pied cattle. I Central Europ Agric 5: 303-308. http://dx.doi.org/10.5513/jcea.v5i4.230

Kumar D, Gupta N, Ahlawat S, Satyanarayana R, Sunder S, Gupta S (2006) Single strand confirmation polymorphism (SSCP) detection in exon I of the lactalbumin gene of Indian Jamunapri milkgoats (Capra hircus). Genetic Mol Biol 29: 271-274. http://dx.doi. org/10.1590/S1415-47572006000200016

Litwińczuk A, Litwińczuk Z, Barłowska J, Florek M (2004) Animal raw materials. Assessment and use. 59 p, PWRiL, Warszawa. (in Polish)

Marchitelli C, Contarini G, De Matteis G, Crisà A, Pariset L, Scatà MC, Catillo G, Napolitano F, Moioli B (2013) Milk fatty acid variability: effect of some candidate genes involved in lipid synthesis. I Dairy Res 80: 165-173. https://doi.org/10.1017/S002202991300006X

Miluchová M, Trakovická A, Gábor M (2009) Molecular-genetic detection of genes CSN3 and LGB in population of Slovak Pinzgau breed by multiplex PCR-RFLP method. Acta Fytotech Zootech Special issue: $450-454$

Miluchová M, Gábor M, Trakovická A (2014) Analysis of genetic structure in Slovak Pinzgau cattle using five candidate genes related to milk production traits. Genetika 46: 865-875. https://doi. org/10.2298/GENSR1403865M

Nei M (1973) Analysis of gene diversity in subdivided populations. Proc Nat Acad Sci US A 70: 3321-3323

Patel RK, Chauhan JB, Singh KM, Soni KJ (2007) Allelic frequency of kappa-casein and beta-lactoglobulin in Indian crossbred (Bos taurus $\times$ Bos indicus) dairy bulls. Turk I Vet Anim Sci 31: 399-402

Riaz MN, Malik NA, Nasreen F, Qureshi JA (2008) Molecular marker assisted study of kappa-casein gene in Nili-ravi (buffalo) breed of Pakistan. Pakistan Vet J 28: 103-106
Robitaille G, Britten M, Morisset J, Petitclerc D (2002) Quantitative analysis of $\beta$-lactoglobulin $\mathrm{A}$ and $\mathrm{B}$ genetic variants in milk of cows $\beta$-lactoglobulin $\mathrm{AB}$ throught lactation. J Dairy Res 69: 651-654. https://doi.org/10.1017/S0022029902005733

SAS Institute Inc. (2011) Administering SAS ${ }^{\circledR}$ Enterprise Guide ${ }^{\circledR}$ 5.1. Cary, NC: SAS Institute Inc, Version 9.3

Schlieben S, Erhard G, Senft B (1991) Genotyping of bovine kappa-casein following DNA sequence amplification and direct sequencing of kappa-CNE PCR product. Anim Genet 22: 333-342

Šimko M, Bíro D, Juráček M, Gálik B, Rolinec M (2014) Nutrition and feeding as a critical point of milk production. In Biotechnology and Animal Food Quality. Chrenek P ed. SPU, Nitra, 137 p. ISBN 978-80-552-1198-5

Sitkowska B, Neja W, Wiśniewska E (2008) Relations between kappa-casein polymorphism (csn3) and milk performance traits in heifer cows. J Cent Eur Agric 9: 641-644. http://dx.doi.org/10.5513/ jcea.v9i4.716

Št'astná D, Št'astný P (2015a) Microstructural changes of cows uterus in an infection caused by Haemophilus somnus. I Cent Eur Agric 16: 269-288. http://dx.doi.org/10.5513/JCEA01/16.3.1620

Št'astná D, Št'astný P (2015b) Postpartum anestrus in cow. SPU, Nitra, 132 p. ISBN 978-80-552-1310-1 (in Slovakian)

Št'astná D, Št'astný P (2016) Št’astná D, Št’astný P (2016) Effect of heat stress on reproduction and production in cow. SPU, Nitra, 72 p. ISBN 978-80-552-1562-4 (in Slovakian)

Stoop WM, Schennink A, Visker MHPW, Mullaart E, Van Arendonk JAM, Bovenhuis H (2009) Genome-wide scan for bovine milk-fat composition: I: quantitative trait loci for short- and medium-chain fatty acids. J Dairy Sci 92: 4664-4675. https://doi.org/10.3168/ ids.2008-1966

Vidra A, Kovalč́k E, Bučko O, Vaňo M (2000) Analysis of milk yield in selected breeds of Pinzgauer cattle. Proceedings "Current problems solved in Agrocomplex", Nitra, pp. 111-113. ISBN 80-7137801-1 (in Slovakian)

Vidra A, Kovalč́k E, Bučko O, Vaňo M (2001) Milk yield in selected protected species of Pinzgauer cattle. Professional seminar of doctoral students and students "Genetics and animal breeding". Přerov, Česká republika, 14.9.2001, pp. 108-110. ISBN 80-7157-532-1 (in Slovakian)

Ziemiński R, Juszczak J, Czarnik U, Ćwikła A, Zabolewicz T, Walawski K (2005) Association between milk protein polymorphism and variability of milk yield and milk components in the herd of blackand-white cows from agricultural factory Kietrz. Acta Scient Pol Zoot 4: 163-170 (in Polish) 